\title{
A Study of Solar Desalination Still Combined with Air-Conditioning System
}

\author{
Z. S. Abdel-Rehim ${ }^{1}$ and A. Lashine ${ }^{2}$ \\ ${ }^{1}$ Mechanical Engineering Department, National Research Center, Dokki, Giza 12311, Egypt \\ ${ }^{2}$ Mechanical Engineering Department, Faculty of Engineering, Benha University, Egypt
}

Correspondence should be addressed to Z. S. Abdel-Rehim, abdelrehimz@yahoo.com

Received 3 April 2012; Accepted 29 April 2012

Academic Editors: E. R. Bandala and B. Chen

Copyright (C) 2012 Z. S. Abdel-Rehim and A. Lashine. This is an open access article distributed under the Creative Commons Attribution License, which permits unrestricted use, distribution, and reproduction in any medium, provided the original work is properly cited.

\begin{abstract}
A study of solar desalination still combined with air-conditioning system is presented in this work. Combining the solar still with the air-conditioning system can increase the condensate output from the solar still while meeting the cooling load needs. The operation of the combined solar distillation and air-conditioning system, that utilized the heat rejected by the condenser and the heat sink of the evaporator, has been tested to obtain the distillate output from the solar still during the air-conditioning of a space application. Experimental work of the present system is carried out in June 2009 (summer month), in Cairo, Egypt. The present problem is tested to use the integrated system operation for already utilizing air-conditioning energy consumption; that is, meeting the hourly air-conditioning load and the daily fresh water production. The system is tested for day and nighttimes of operation of the combined system for the summer month: June 2009, Cairo, Egypt. Economic study evaluation is presented. The results show that the maximum fresh water productivity through June is 29 Liters in daytime of June 52009 and 37 liters in nighttime (nocturnal time) of June 3 2009. The present system more efficient in day time (8:00 AM-8:00 PM) and night time (8:00 PM-8:00 AM). Therefore, the maximum efficiency is recorded 40\% for the present system in daytime, $36 \%$ in nighttime, and $25 \%$ for conventional solar still. COP increases with inside temperature $\left(T_{i}\right)$, however it decreases with outside temperature $\left(T_{\mathrm{amb}}\right)$. The average cost of one liter of distillate water from the present combined system $=0.021441$ (LE).
\end{abstract}

\section{Introduction}

The shortage of drinking water is expected to be the biggest problem of the world in this century due to unsustainable consumption rates and population growth. Pollution of fresh water resources (rivers, lakes, and underground water) by industrial wastes has heightened the problem. About 70\% of the earth is covered by water, and sea water represents about $97 \%$ of the water on the planet, and the remaining is fresh water; thus there is a shortage of potable water in many countries around the world. The rural and remote regions in the Middle East countries do not have access to good quality drinking water and as a result they relied on low cost options for producing water from salty aquifers such as solar desalination. Many researchers have developed mathematical models, and experimentally tried to improve the design of the conventional solar still in order to increase its daily productivity. Tiwari et al. [1] reported that the solar still output can be increased by decreasing the temperature of the glass cover through flowing water over the glass cover. AlHinai et al. [2] also reported that the condensate output of a double-effect solar still is twice that of a single-effect solar still, when water is passed between the double glass layers and therefore dropping its temperature. Other researchers such as Nawayseh et al. [3] focused on the reclamation of the condensing energy by transferring the latent heat of condensation to the feed saline water before it enters the solar still. Nawayseh reported that the fresh water output considerably increased in comparison to the water output of a conventional unit. Other researchers considered a simultaneous increase of the evaporator temperature and lowering the temperature of the glass cover, Rahim [4] reported that the enhancement of the efficiency of a conventional solar still is related to the temperature difference between the 
evaporating and condensing zones. Since the solar stills are not reliable in producing fresh water, other researchers considered combining the air-conditioning system with desalination. Yuan et al. [5] integrated desalination and air-conditioning system utilizing the heat rejected by the condenser and the heat sink of the evaporator to evaporate the sea water and then condense it on the cold surfaces of the evaporator. The water output of the combined system exceeds the output of an improved solar still that harasses the latent heat of condensation and lowers the temperature of the cover glass. However, the conventional solar still component does not exist in the integrated system of Yuan et al. [5], and it relies on electrical energy to produce fresh water. If the air-conditioning system is not running, then no potable water can be produced. Evaporation rate as a function of water salinity is studied by AI-Shammiri [6]. The economic feasibility of small solar MED seawater desalination plants for remote areas is presented by El-Nashar [7]. Kusuda et al. [8] developed a simplified calculation method of seasonal performance of residential HVAC equipment, which could be used within the variable base degree-day method.

The objective of this work is to test and experiment the operation of a combined solar still desalination unit with air-conditioning system and to study the enhancement in distillate output and system performance to meet fresh water production and a specified cooling load.

\section{Governing Equations of the System Components}

2.1. Solar Still. The conventional solar still consists of a single basin of L-shape contains brine water and glass cover. At any instant of time, the still produces an amount of distillate water equal to $W_{p}$, Liter $/ \mathrm{m}^{2}$ per unit area of the glass cover. $T_{w}, T_{g}$, and $T_{a},{ }^{\circ} \mathrm{C}$ are the average temperatures of basin water, the glass cover and ambient, respectively. The still receives solar radiation per unit area of $I,\left(\mathrm{~W} / \mathrm{m}^{2}\right)$. The operation of solar desalination system is governed by the following heat balance equations:

2.1.1. Solar Energy Equations of Glass Cover $\left(q_{g}\right)$. The thermal energy balance equations of the glass cover are given as:

$$
q_{g}=\alpha_{g} I-q_{L g}\left(\mathrm{~W} / \mathrm{m}^{2}\right),
$$

where

$$
\begin{gathered}
q_{L g}=q_{c g}+q_{r g}\left(\mathrm{~W} / \mathrm{m}^{2}\right), \\
q_{c g}=h_{c g}\left(T_{g}-T_{a}\right)\left(\mathrm{W} / \mathrm{m}^{2}\right), \\
q_{r g}=\varepsilon_{g} \sigma\left[T_{g}^{4}-\left(T_{a}-11\right)^{4}\right]\left(\mathrm{W} / \mathrm{m}^{2}\right),
\end{gathered}
$$

where: $q_{L g}$ : is the sum heat losses from the glass to the surrounding. $q_{c g}$ : is the heat losses by convection. $q_{r g}$ : is the heat losses by radiation between glass cover and the surrounding. $h_{c g}$ : is the heat transfer coefficient from the glass cover to the surrounding and can be calculated as,
Duffie and Backman [9]:

$$
h_{c g}=5.7+3.8 W_{s}\left(\mathrm{~W} / \mathrm{m}^{2} \mathrm{k}\right),
$$

where $W_{s}$ is the wind speed.

2.1.2. Solar Energy Absorbed by Basin Water $\left(q_{w}\right)$. The thermal energy equations of basin water are expressed as, Rai [10]:

$$
q_{i w}=(\tau \alpha)_{w} I-q_{L w}\left(\mathrm{~W} / \mathrm{m}^{2}\right),
$$

where

$$
q_{i w}=q_{e w}+q_{r w}+q_{c w}+q_{L b}\left(\mathrm{~W} / \mathrm{m}^{2}\right),
$$

where $q_{i w}$ is the input thermal energy to the basin water and can be obtained from the following equations.

(1) $q_{e w}$ is evaporated heat transfer rate at the saline water surface and a function of the distilled production of the fresh water $\left(W_{h}\right)$. It is calculated from the following relationship:

$$
q_{\text {ew }}=\frac{W_{h} \times 10^{-6} \times \rho_{w} \times L_{w}}{3600}\left(\mathrm{~W} / \mathrm{m}^{2}\right),
$$

where $L_{w}$ is the latent heat of water evaporation at the cover temperature, and equals $2.35 \times 10^{6} \mathrm{~J} / \mathrm{kg}$. The performance of the system is the ratio of the actual distilled water obtained per day to the energy input and can be computed as follows:

$$
\eta_{d}=\frac{W_{d} \times 10^{-6} \times \rho_{w} \times L_{w}}{3600 \times I}=\frac{2.35 \rho_{w} W_{d}}{3600 \times I} .
$$

(2) $q_{r w}$ is the heat transfer rate by radiation between the saline water and the inner glass cover surface, and is given as:

$$
q_{r w}=\sigma F_{(w-g)}\left[\varepsilon_{w} T_{w}^{4}-\varepsilon_{g} T_{g}^{4}\right]\left(\mathrm{W} / \mathrm{m}^{2}\right),
$$

where $F_{(w-g)}$ is the radiation shape factor from saline water to the inner glass surface and equals here (0.9).

(3) $q_{c w}$ is the convective heat transfer rate between the saline water and the inner glass cover surface, and is calculated as:

$$
q_{c w}=h_{c w}\left(T_{w}-T_{g}\right)\left(\mathrm{W} / \mathrm{m}^{2}\right),
$$

where $h_{c w}$ is the convective heat transfer coefficient and is calculated as:

$$
\begin{aligned}
& h_{c w}= 8.84 \times 10^{-4} \times\left(T_{w}-T_{g}\right) \\
& \times\left(\left(T_{w}-T_{g}\right)+\left(\frac{P_{w}-P_{g}}{2.65 *\left(P_{t}-P_{w}\right)}\right)\right. \\
&\left.\times T_{w}\right)^{1 / 3}\left(\mathrm{~W} / \mathrm{m}^{2} \cdot{ }^{\circ} \mathrm{C}\right) .
\end{aligned}
$$

(4) $q_{L b}$ is the heat losses from the basin base to the ground and can be calculated as:

$$
Q_{L b}=h_{L b}\left(T_{w}-T_{a}\right)\left(\mathrm{W} / \mathrm{m}^{2}\right),
$$



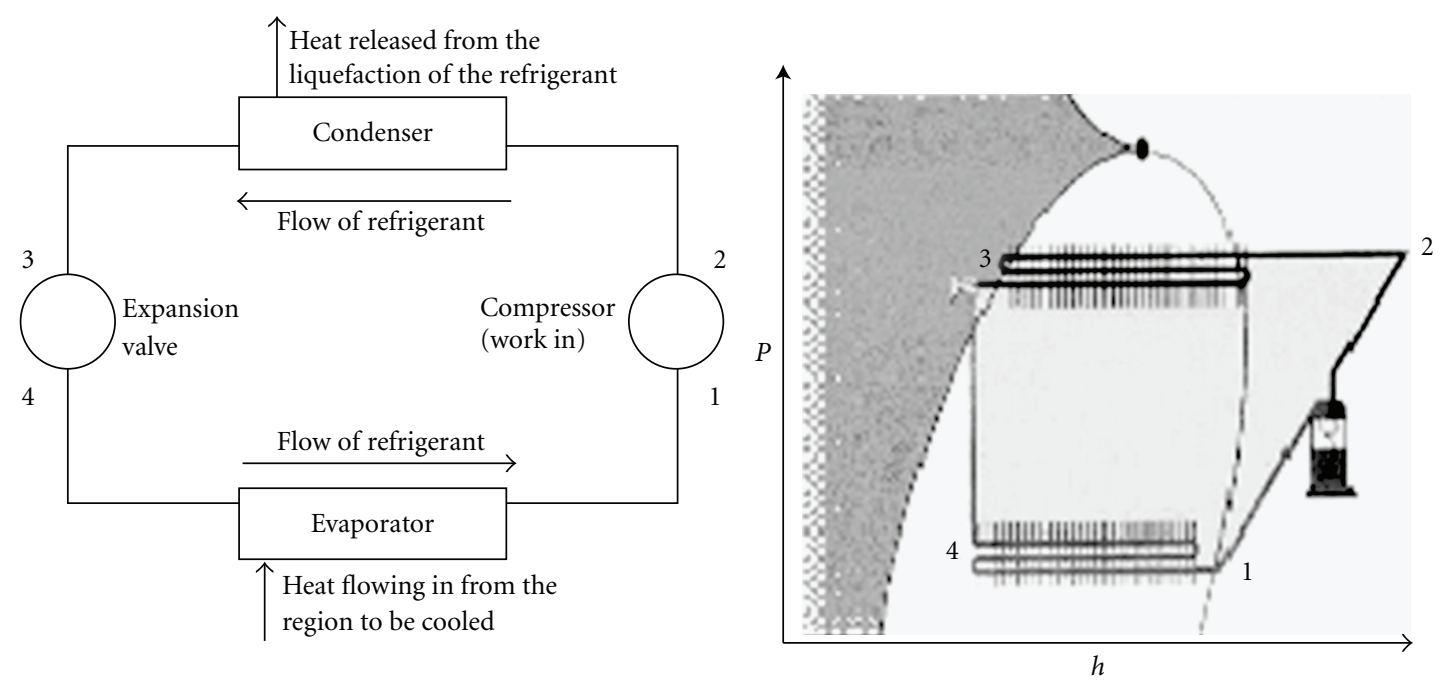

FIGURE 1: The vapor compression refrigeration unit and basic vapor compression cycle used in the present system.

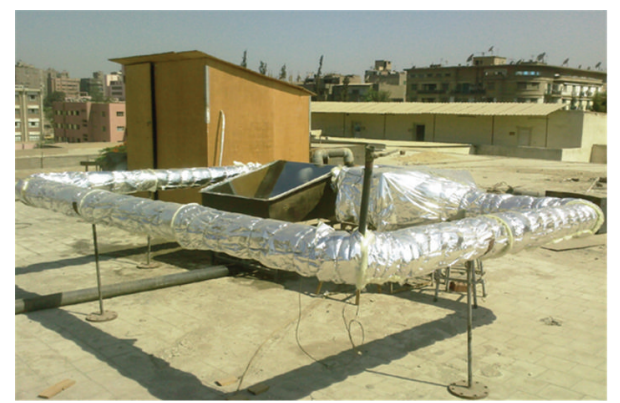

FIGURE 2: photography picture of the solar still combined with airconditioning system in front view, Cairo, Egypt.

where $h_{L b}$ is the convective heat transfer coefficient of the basin base, and it is function of thermal conductivity. The thickness of the insulation material which can be calculated as follows:

$$
h_{L b}=\frac{K_{\text {in }}}{X_{\text {in }}}\left(\mathrm{W} / \mathrm{m}^{2} \mathrm{k}\right) \text {, }
$$

(see Rai [10]).

2.2. Compression Refrigeration Unit. The major part of refrigeration systems operated electrically are based on the vapor compression refrigeration cycle, Dincer [11], which is composed of four basic components: evaporator, compressor, condenser, and expansion valve, as shown in Figure 1. Applying the first law of thermodynamics to the whole cycle, and to each of its components, Engel and Boles [12], neglecting changes in kinetic and potential energy, and if $\dot{m}$ is the refrigerant mass flow rate in the system, it is possible to calculate the different energy fluxes in the cycle by the following set of equations.

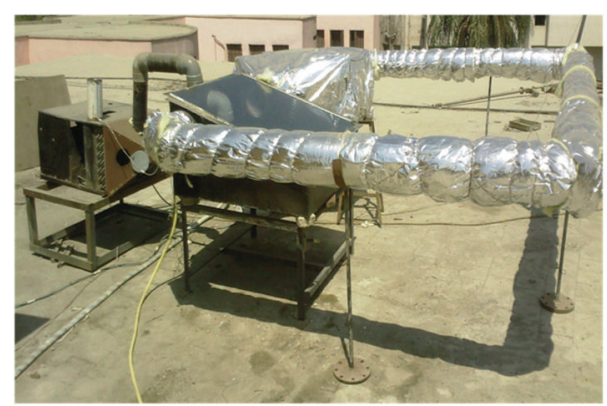

FIgURE 3: photograph picture of the solar still combined with airconditioning system in side view, Cairo, Egypt.

(1) First law of thermodynamics

$$
Q_{\text {evap }}^{\bullet}+Q_{\text {cond }}^{\bullet} \dot{W}=0,
$$

(2) Evaporator (refrigeration effect):

$$
Q_{\text {evap }}^{\bullet}=\dot{m}\left(h_{1}-h_{4}\right) \text {, }
$$

(3) Compressor (compression power):

$$
\dot{W}=\dot{m}\left(h_{2}-h_{1}\right),
$$

(4) Condenser (condensation heat):

$$
Q_{\text {cond }}^{\bullet}=\dot{m}\left(h_{3}-h_{2}\right) \text {, }
$$

(5) Expansion valve: $h_{4}=h_{3}$.

The coefficient of performance (COP) is then given by:

$$
\mathrm{COP}=\frac{Q_{\text {evap }}^{\bullet}}{\dot{W}}=\frac{h_{1}-h_{4}}{h_{2}-h_{1}}
$$




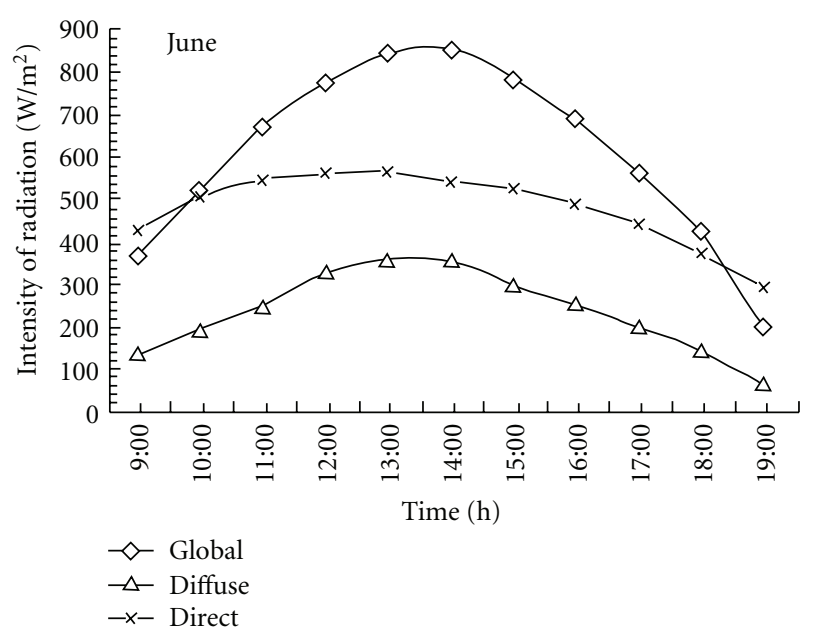

FIGURE 4: Average of solar intensity of Cairo site in June.

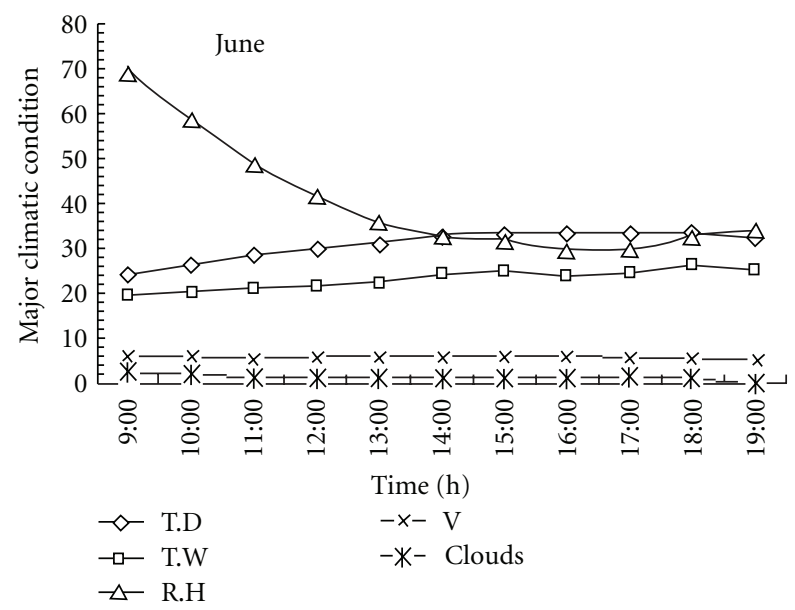

FIgURE 5: Climate conditions of Cairo site in June.

where $h_{i}$ is the enthalpy, $(\mathrm{kJ} / \mathrm{kg}), Q_{\text {evap }}^{\cdot}$ is heat power extracted from the evaporator $(\mathrm{kW}), Q_{\text {cond }}^{*}$ is heat power released in the condenser, $(\mathrm{kW}), \dot{W}$ is compressor mechanical power $(\mathrm{kW})$.

COP values are always positive and usually greater than one, due to the fact that the refrigeration effect is greater than the compression power.

\section{Experimental Work}

The system is composed of a conventional solar still of $1 \mathrm{~m}^{2}$, compressor of $2.5 \mathrm{HP}, 220 \mathrm{Volt}, 50 \mathrm{~Hz}, 18 \mathrm{amb}$., and R22 of $1.425 \mathrm{gm}$, condenser is rectangular of $54.5 \times 61 \mathrm{~cm}^{2}$, expansion valves and evaporator cooling coil is rectangular of $30.5 \times 10^{4} \mathrm{~cm}^{2}$.

There is simultaneous meeting of fresh water production and the air-conditioning requirement in location of Cairo, Egypt without exceeding the cooling capacity of the airconditioning system.

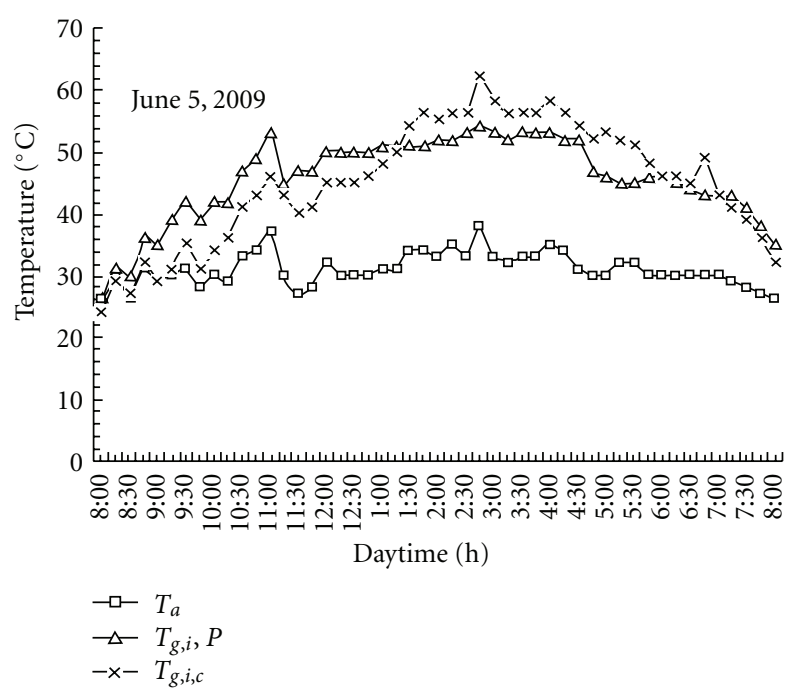

FIGURE 6: Variation of ambient and inner glass covers temperature of conventional still and present still system.

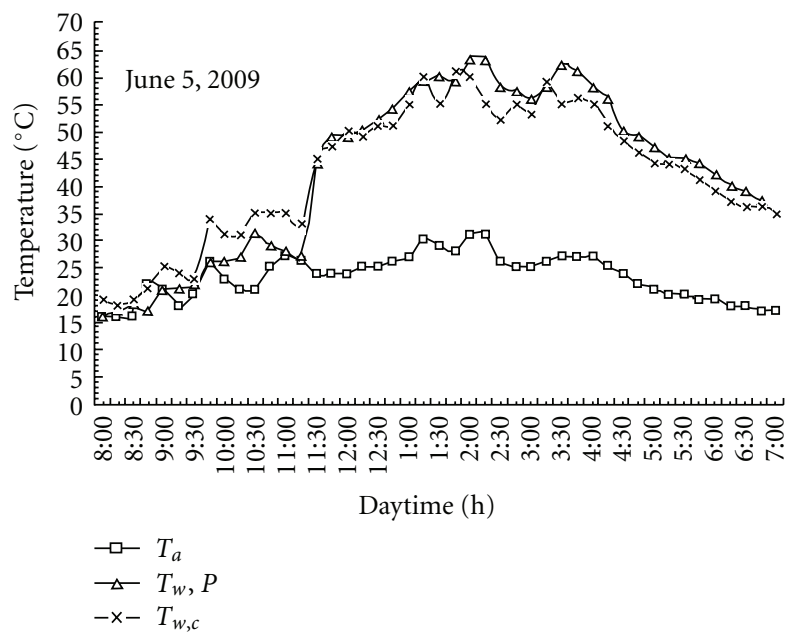

Figure 7: Variation of ambient, water in basin temperature of conventional still and present still system.

The experimental setup of the present system is built under the climate conditions of Cairo, Egypt to enhance the performance of the solar desalination system, Figures 2 and 3. Five experiments are carried out in summer month (June 2009) for day and nighttimes as case study. Measurements of components system temperature and fresh water productivity are recorded for the conventional solar still and the present solar desalination combined with air-condition system. Type- $\mathrm{K}$ thermocouples $\left( \pm 5^{\circ}\right)$, digital temperature devise, and remote control unit are used for measuring the components system temperature, and graduated jar is used for measuring the fresh water yield. The forecast of typical climate conditions of Cairo site, Egypt at the selected month are obtained from the "Egyptian Solar Radiation Atlas" of Geophysical Institute Shaltout [13]. Figure 4 shows the average of solar intensity in June for the experimental work. 


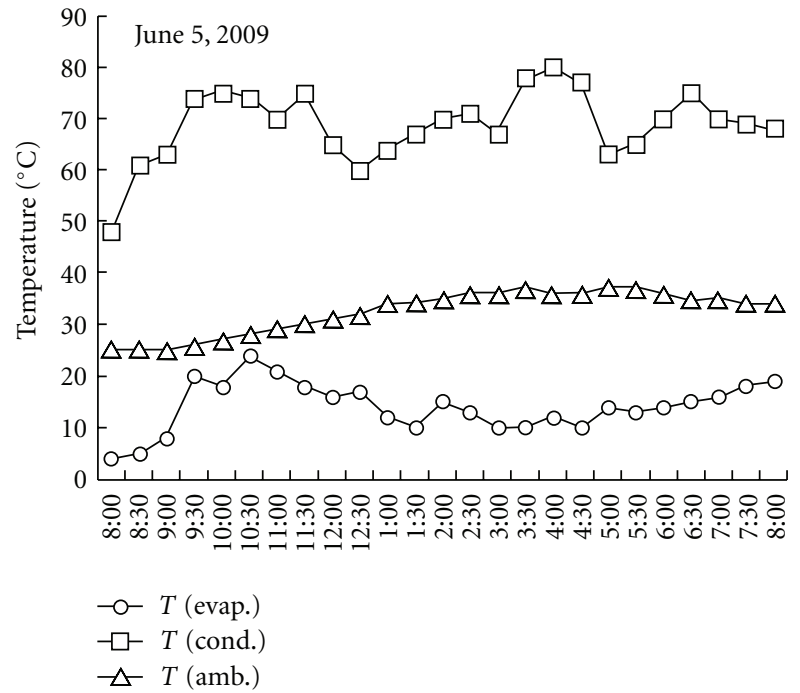

FiguRE 8: Variation of ambient, evaporator, and condenser temperature of the present system.

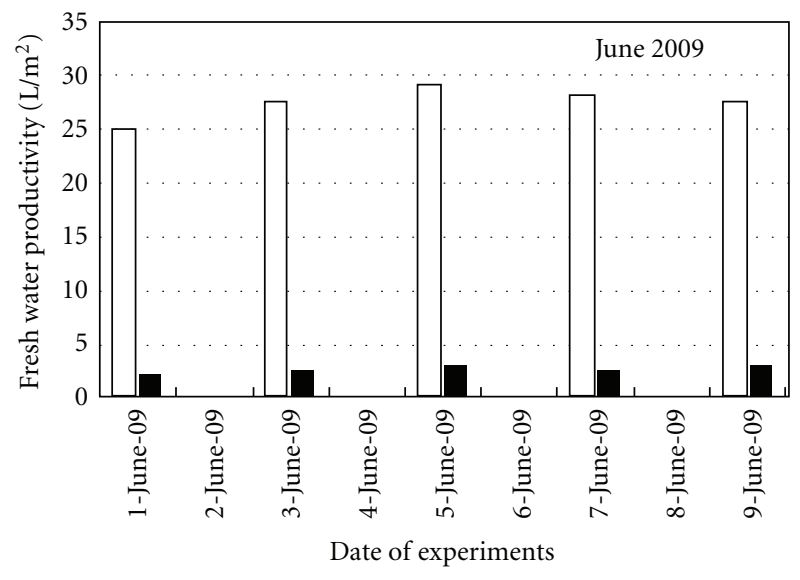

$\square$ Present system

- Conv. still

FIGURE 9: Water productivity for the present system and the conventional still during daytime for the five experiments in June 2009 in Cairo site, Egypt.

Figure 5 shows the forecast of the typical climatic conditions of the experimental work for Cairo site.

\section{Economic Study Evaluation}

For a desalination unit, the items of annual cost would be; capital cost of the components, fresh water production, and maintenance and operating expenses. The maintenance and operating expenses are estimated as $4 \%$ of capital cost. A present system with proper maintenance can serve up to 10 years. The salvage value of the present still is neglected. Table 1 gives the description, quantities, and costs of the components by Egyptian pounds (LE) of the present system in 2009.

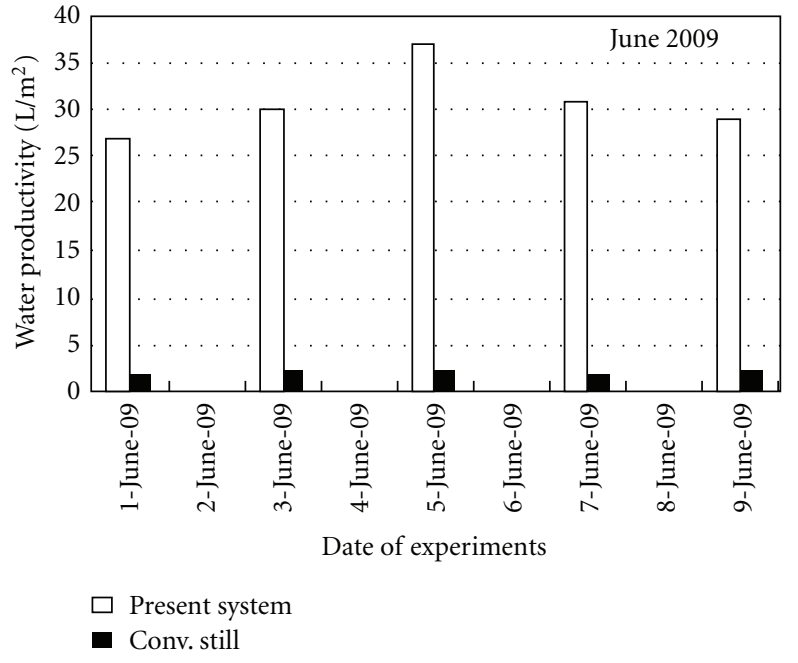

FIGURE 10: Water productivity for the present system and the conventional still during nighttime for the five experiments in June 2009 in Cairo site, Egypt.

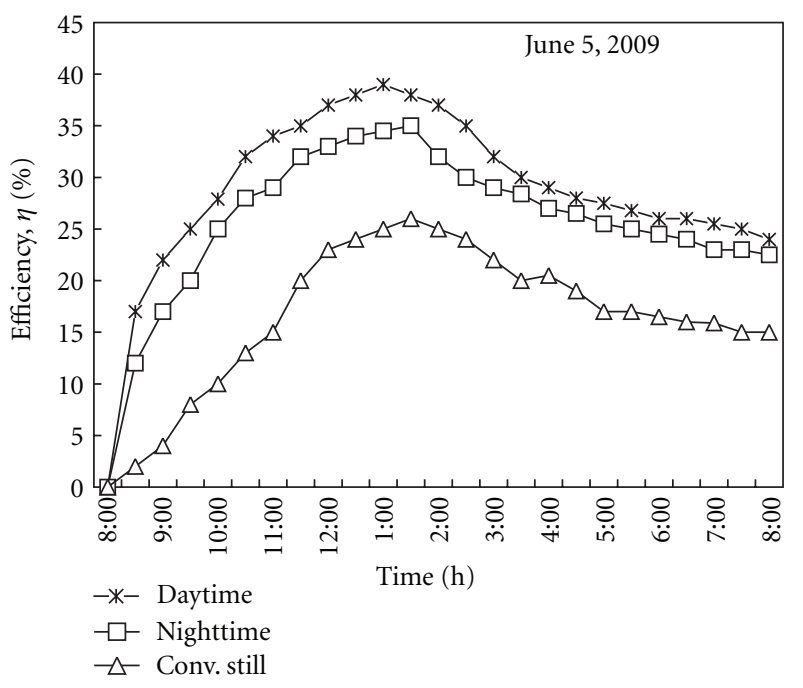

FIGURE 11: Efficiency for the present system and the solar conventional still during day and nighttime in June 52009 in Cairo site, Egypt.

The annual cost of the present system $=3795 / 10=379.5$ (LE) and the daily cost $=379.5 / 300=1.265$ (LE). The average cost of one liter of distillate water from the present system $=1.265 /(29$ liter in daytime +30 liter in nighttime of June 5 2009) $=0.021441(\mathrm{LE})$.

Note. The cost of the conventional system per 10 years $=958$ (LE), the annual cost $=95.8(\mathrm{LE})$, and the daily cost $=0.26$ (LE). The average cost of one liter of distillate water from the conventional system $=0.0743(\mathrm{LE})$ which the average distillate water about $3.5 \mathrm{liter} / \mathrm{m}^{2}$ day.

From the previous economic study, the present system is more economical and efficient. 
TABLE 1: The description, quantities, and costs of the components of the present solar still by Egyptian pounds (LE) (US\$ $\approx 6.0$ LE), 2009.

\begin{tabular}{|c|c|c|c|}
\hline Components & Specification & No. $\times$ cost, $(\mathrm{LE})$ & Total cost \\
\hline Black iron sheet, $\mathrm{m}$ & $(1 \times 2) \mathrm{m}, 2 \mathrm{~mm}$ thickness & $1 \times 150$ & 150 \\
\hline Still supported, (H-section), m & $5 \mathrm{~m}, 2 \mathrm{~mm}$ thickness & $5 \times 20$ & 100 \\
\hline Glass cover, sheet & $1000 \times 1000 \times 6 \mathrm{~mm}$ & $1 \times 85$ & 85 \\
\hline Nozzle and insulation & Galvanized iron and $3 \mathrm{~m}$ glass wool thermal insulation & $1 \times 400$ & 400 \\
\hline Silicon rubber & White & $3 \times 10$ & 30 \\
\hline Plastic tank, Liter & 20 & $1 \times 10$ & 10 \\
\hline Compression refrigerant units & Compressor of $2.5 \mathrm{HP}$, condenser, evaporator, and expansion valves & $1 \times 2500$ & 2500 \\
\hline Valves & 1 inch & $3 \times 15$ & 45 \\
\hline Foam, $5 \mathrm{~cm}$ thickness, sheet & $2 \mathrm{~m}^{2}$ & $3 \times 15$ & 45 \\
\hline Glass wool insulation, $\mathrm{m}$ & $5 \mathrm{~m}$ & $5 \times 15$ & 75 \\
\hline Elbow & 8 inch diameter & $4 \times 35$ & 140 \\
\hline Plastic pipes & $1 \mathrm{~m}$ length and 8 inch diameter & $4 \times 35$ & 140 \\
\hline Added costs & Claim of this work + electrical power consumption & 75 & 75 \\
\hline Total costs & The present system & $1 \times 4083$ & 3795 \\
\hline
\end{tabular}

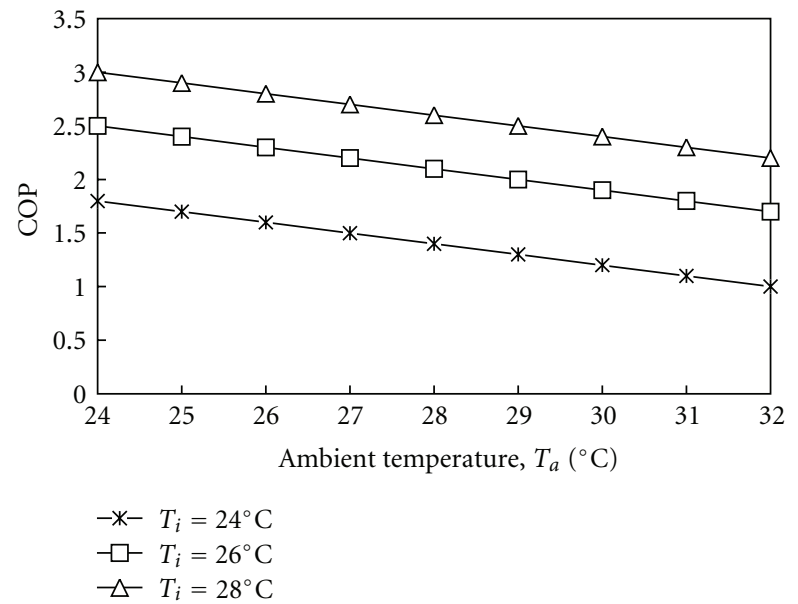

FIGURE 12: COP as a function of outside air temperature for three different indoor air temperatures for the present vapor compression refrigerant system.

\section{Results and Discussions}

The temperature variation of the components, accumulated fresh water per day and nighttimes, and the performance for the present solar desalination system and the conventional solar still, and COP of the present refrigerant system under case study are presented and illustrated through Figures 612. According to the hourly variation of the solar radiation, I, for the conventional and present solar desalination systems at selected days; June 2009, the results have been illustrated.

The variation of the ambient, $T_{a}$ and inner glass cover temperatures, $T_{g}$, are varied and have peak values around the noon interval for the present system and conventional solar still. The experiment was recorded from (8:00 AM-8:00 PM) in June 52009 for Cairo site, Egypt, Figure 6. The hourly variation of basin water temperatures, $T_{w}$ and ambient temperature, $T_{a}$, for the present system and conventional solar still, in June 52009 for Cairo site, Egypt are plotted in Figure 7. It is noticed, as time goes on, all temperatures increase and begin to decrease after 4:00 PM with respect to the variation of the solar radiation, although the temperature values of the present system are higher than the conventional solar still.

Variation of ambient, evaporator, and condenser temperature of the present system is given in Figure 8. It indicates the vapor compression refrigerant effect as function of hourly time during daytime.

Fresh water productivity for the present system and the conventional still during daytime (8:00 AM-8:00 PM) for the five experiments in June 2009 in Cairo site, Egypt is shown in Figure 9. It is found that the amount of fresh water yield in daytime of the present system is very high than the conventional solar still in all five experiments.

Figure 10 shows the water productivity for the present system and the conventional still during nighttime (8:00 PM-8:00 AM) for the five experiments in June 2009 in Cairo site, Egypt. Also, the amount of fresh water productivity during nighttime of the present system which is very high compared with the conventional solar still in all five experiments.

The performance of the present work and conventional solar still is shown in Figure 11. In this figure, efficiency for the present system and the conventional still during day and nighttime in June 52009 in Cairo site, Egypt. It can be seen that the present system more efficient in day (8:00 AM8:00 PM) and nighttime (8:00 PM-8:00 AM). Therefore, the maximum efficiency is recorded $40 \%$ for the present system in daytime, $36 \%$ in nighttime, and $25 \%$ for conventional solar still.

$\mathrm{COP}$ as a function of outside air temperature for three different indoor air temperatures for the present vapor compression refrigerant system is shown in Figure 12. COP values are always positive and usually greater than one, due to the fact that the refrigeration effect is greater than the compression power. It is found that COP increases with 
inside temperature $\left(T_{i}\right)$, however, decreases with outside temperature $\left(T_{\mathrm{amb}}\right)$.

\section{Conclusions}

In this paper, and based on the results, the concluded points are drawn as the following.

(1) As time goes on, all temperatures increase and begin to decrease after 4:00 PM with respect to the variation of the solar radiation, although the temperature values of the present system are higher than the conventional solar still.

(2) The present system more efficient in daytime (8:00 AM-8:00 PM) and nighttime (8:00 PM-8:00 AM). Therefore, the maximum efficiency is recorded $40 \%$ for the present system in daytime, $36 \%$ in nighttime, and $25 \%$ for conventional solar still.

(3) COP values are always positive and usually greater than one, due to the fact that the refrigeration effect is greater than the compression power.

(4) COP increases with inside temperature $\left(T_{i}\right)$, however decreases with outside temperature $\left(T_{\mathrm{amb}}\right)$.

\section{References}

[1] G. N. Tiwari, V. Dimri, U. Singh, A. Chel, and B. Sarkar, "Comparative thermal performance evaluation of an active solar distillation system," International Journal of Energy Research, vol. 31, no. 15, pp. 1465-1482, 2007.

[2] H. Al-Hinai, M. S. Al-Nassri, and B. A. Jubran, "Parametric investigation of a double- e $\sim$ e Gt solar still in comparison with a single-effect solar still," Desalination, vol. 150, no. 1, pp. 7583, 2002.

[3] N. K. Nawayseh, M. M. Farid, S. Al-Hallaj, and A. R. Al-Timimi, "Solar desalination based on humidification process-I. Evaluating the heat and mass transfer coefficients," Energy Conversion and Management, vol. 40, no. 13, pp. 14231439, 1999.

[4] N. H. A. Rahim, "Utilisation of new technique to improve the efficiency of horizontal solar desalination still," Desalination, vol. 138, no. 1-3, pp. 121-128, 2001.

[5] G. Yuan, L. Zhang, and H. Zhang, "Experimental research of an integrative unit for air-conditioning and desalination," Desalination, vol. 182, no. 1-3, pp. 511-516, 2005.

[6] M. Al-Shammiri, "Evaporation rate as a function of water salinity," Desalination, vol. 150, no. 2, pp. 189-203, 2002.

[7] A. M. El-Nashar, "The economic feasibility of small MED seawater desalination plants for remote arid areas," Desalination, vol. 134, no. 1-3, pp. 173-186, 2001.

[8] T. Kusuda, T. Alereza, and L. Hovander, "Development of equipment seasonal performance models for simplified energy analysis methods," ASHRAE Transactions, vol. 88, pp. 249262, 1982.

[9] J. A. Duffie and W. A. Backman, Solar Engineering of Thermal Processes, John Wiley \& Sons, New York, NY, USA, 2nd edition, 1991.

[10] G. D. Rai, Solar Energy Utilization, Textbook for Engineering Students, Khanna Publishers, New Delhi, India, 1980.

[11] I. Dincer, Refrigeration Systems and Applications, John Wiley \& Sons, 2003.
[12] Y. C. Engel and M. Boles, Thermodynamics, McGraw-Hill, 1994.

[13] M. Shaltout, Egyptian Solar Radiation Atlas, Geography Institute, Cairo, Egypt, 1998. 

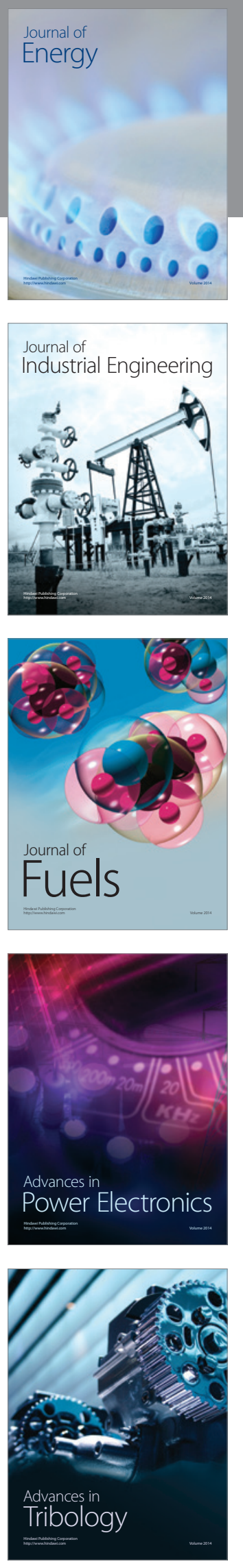
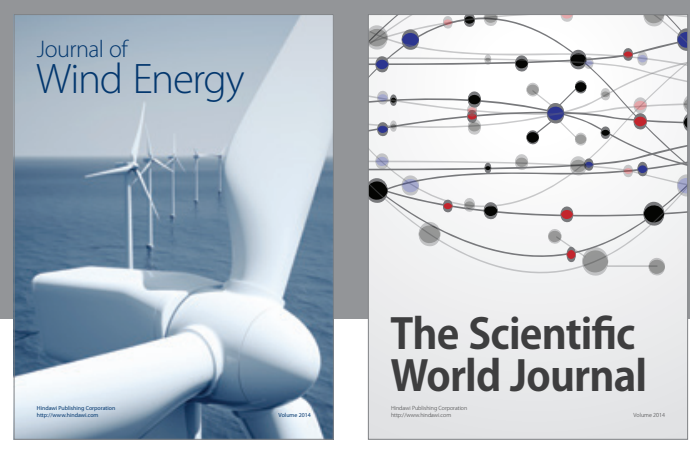

The Scientific World Journal

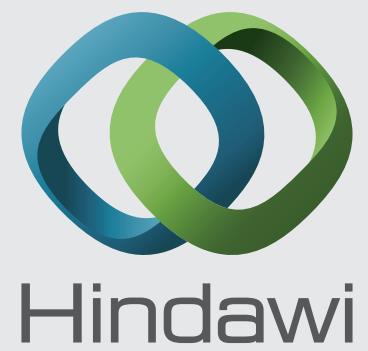

Submit your manuscripts at http://www.hindawi.com
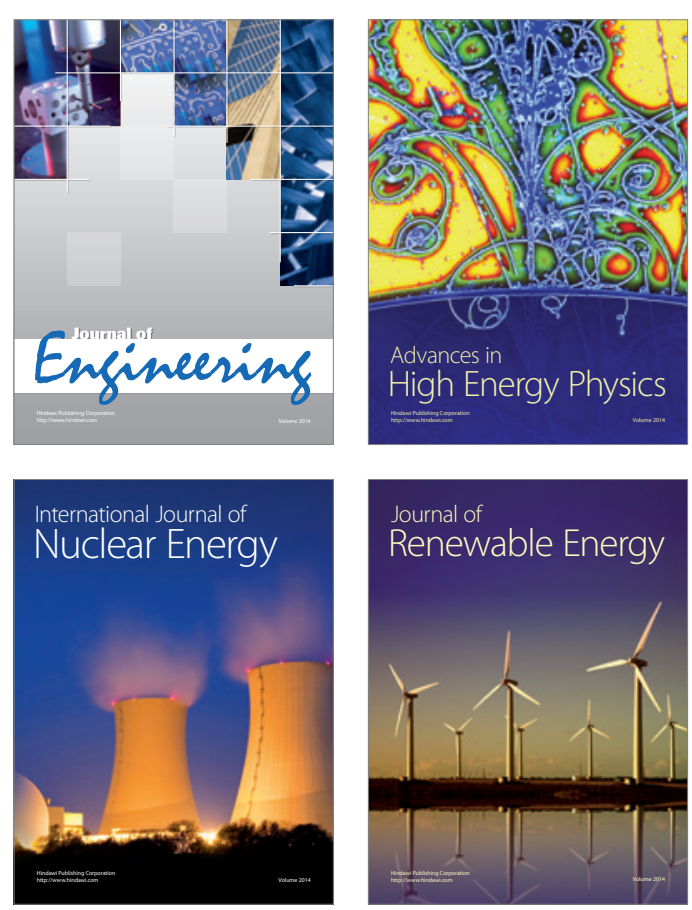

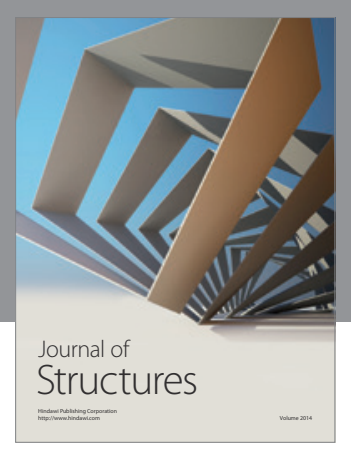

Rotating
Mechinery
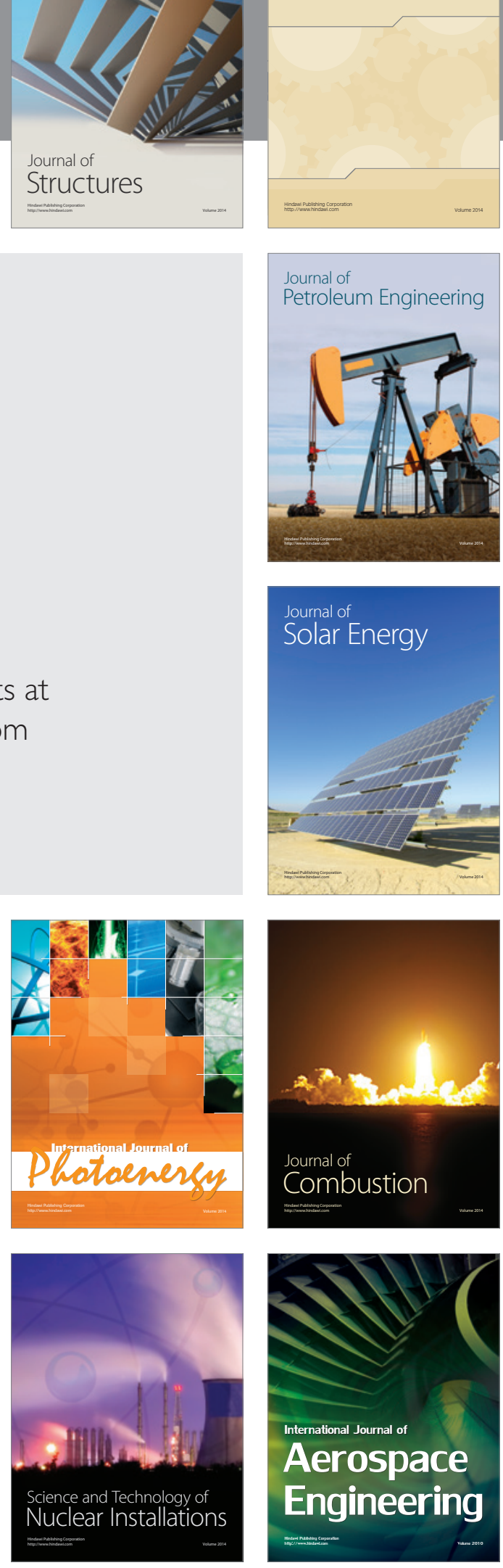